\title{
Identification problems in personality psychology
}

Citation for published version (APA):

Borghans, L., Golsteyn, B. H. H., Heckman, J., \& Humphries, J. E. (2011). Identification problems in personality psychology. Researchcentrum voor Onderwijs en Arbeidsmarkt, Faculteit der Economische Wetenschappen. ROA Research Memoranda No. 004 https://doi.org/10.26481/umaror.2011004

Document status and date:

Published: 01/01/2011

DOI:

10.26481/umaror.2011004

Document Version:

Publisher's PDF, also known as Version of record

\section{Please check the document version of this publication:}

- A submitted manuscript is the version of the article upon submission and before peer-review. There can be important differences between the submitted version and the official published version of record.

People interested in the research are advised to contact the author for the final version of the publication, or visit the DOI to the publisher's website.

- The final author version and the galley proof are versions of the publication after peer review.

- The final published version features the final layout of the paper including the volume, issue and page numbers.

Link to publication

\footnotetext{
General rights rights.

- You may freely distribute the URL identifying the publication in the public portal. please follow below link for the End User Agreement:

www.umlib.nl/taverne-license

Take down policy

If you believe that this document breaches copyright please contact us at:

repository@maastrichtuniversity.nl

providing details and we will investigate your claim.
}

Copyright and moral rights for the publications made accessible in the public portal are retained by the authors and/or other copyright owners and it is a condition of accessing publications that users recognise and abide by the legal requirements associated with these

- Users may download and print one copy of any publication from the public portal for the purpose of private study or research.

- You may not further distribute the material or use it for any profit-making activity or commercial gain

If the publication is distributed under the terms of Article $25 \mathrm{fa}$ of the Dutch Copyright Act, indicated by the "Taverne" license above, 


\section{Identification Problems in Personality Psychology}

Lex Borghans

Bart H.H. Golsteyn

James Heckman

John Eric Humphries

\section{ROA Research Memorandum}

ROA-RM-2011/4

Research Centre for Education and the Labour Market Maastricht University

P.O. Box 616,6200 MD Maastricht, The Netherlands

$\mathrm{T}+31433883647 \mathrm{~F}+31433884914$

secretary-roa-sbe@maastrichtuniversity.n www.roa.nl 


\title{
Identification Problems in Personality Psychology
}

\author{
Lex Borghans \\ Bart H.H. Golsteyn \\ James Heckman \\ John Eric Humphries
}

ROA-RM-2011/4*

March 2011

Research Centre for Education and the Labour Market

Maastricht University

P.O. Box 616, 6200 MD Maastricht, The Netherlands

$\mathrm{T}+31433883647 \mathrm{~F}+31433884914$

secretary-roa-sbe@maastrichtuniversity.nl

www.roa.nl

\footnotetext{
* The ROA Research Memorandum Series was created in order to make research results available for discussion, before those results are submitted for publication in journals.
} 


\section{Abstract}

\section{Identification Problems in Personality Psychology**}

This paper discusses and illustrates identification problems in personality psychology. The measures used by psychologists to infer traits are based on behaviors, broadly defined. These behaviors are produced from multiple traits interacting with incentives in situations. In general, measures are determined by these multiple traits and do not identify any particular trait unless incentives and other traits are controlled for. Using two data sets, we show, as an example, that substantial portions of the variance in achievement test scores and grades, which are often used as measures of cognition, are explained by personality variables.

JEL classification: D01, D03, D89

Keywords: identification problem, personality, psychology, achievement test, grades

\section{Lex Borghans}

Department of Economics and ROA

Maastricht University

P.O. Box 616

6200 MD Maastricht

The Netherlands

lex.borghans@maastrichtuniversity.nl
James J. Heckman

Department of Economics

The University of Chicago

1126 E. 59th Street

Chicago, IL 60637

USA

jjh@uchicago.edu

John Eric Humphries

Department of Economics

The University of Chicago

1126 E. 59th Street

Chicago, IL 60637

USA

johneric@uchicago.edu

b.golsteyn@maastrichtuniversity.nl

\footnotetext{
** This research was supported by grants from NIH R01-HD054702 and R01-HD065072; The Institute for New Economic Thinking (INET); A New Science of Virtues: A Project of the University of Chicago; the American Bar Foundation; a conference series from the Spencer Foundation; the JB \& MK Pritzker Family Foundation; the Buffett Early Childhood Fund; and the Geary Institute, University College Dublin, Ireland. The opinions expressed in this report are those of the authors and do not necessarily reflect the views of any of the funders. We thank Tim Kautz for helpful comments. Additional information is presented in a Web Appendix, available at http://jenni.uchicago. edu/identification-problems/.
} 


\section{Introduction}

There is a growing interest in personality psychology by economists to better understand the diversity of responses of agents to similar circumstances. Many economists now include personality measures and proxies for cognition in their empirical analyses. How should one interpret these estimated relationships?

Personality psychology attempts to describe the whole person. ${ }^{1}$ It considers both universal traits and individual differences. It examines the ways in which people are unique. As a sign of its breadth, personality psychology considers both cognitive functioning and personality traits as aspects of personality.

Characterizing what personality psychologists analyze, it is helpful to distinguish personality traits, personality as a response function, and measured personality (Almlund, Duckworth, Heckman et al., 2011). Personality is a response function that maps personality traits to measured (manifest) personality. One leading personality psychologist defines personality traits in the following way:

"Personality traits are the relatively enduring patterns of thoughts, feelings, and behaviors that reflect the tendency to respond in certain ways under certain circumstances.” (Roberts, 2009, p. 140)

This definition, or closely related versions, is used throughout personality psychology. ${ }^{2}$

Roberts' definition of personality traits refers to the stability of certain patterns of conduct, such as actions or responses to situations that people take, including patterns of thoughts or feelings. Perceptions, expectations of future events and preferences also

\footnotetext{
${ }^{1}$ Cervone and Pervin (2009).

${ }^{2}$ However, some personality psychologists use this or a very similar definition to define personality and not personality traits. Thus Cervone and Pervin (2009) define personality as "psychological qualities that contribute to an individual's enduring and distinctive patterns of thinking, feeling and behaving" (p. 8).
} 
shape behavior, feelings and thoughts. In this way, cognitive activities help to determine measured personality. In light of these common-sense observations, how should one interpret widely used measures of personality and cognition?

Many different models of personality have been formulated. ${ }^{3}$ A prototypical model is developed by Roberts (2006). He presents the schematic displayed in Figure 1 to relate personality traits to measured behaviors, thoughts, and feelings. He distinguishes mental abilities from personality traits, although both are aspects of personality broadly defined. These traits and abilities, along with preferences (motives, interests, and values) and narratives (the stories people tell themselves in organizing their lives and making meanings of them), shape a person's identity and reputation. This includes the views of the person by others and the person's perception of how others perceive him. Identity and reputation shape the roles of individuals in the economy and the society to which they belong. Personality is the system of relationships that map traits and other determinants of behavior, thoughts, and feelings into measured actions. ${ }^{4}$ Measured personality results from interactions among the components of the system. Personality traits are only one determinant of measured personality.

Figure 1 about here

Figure 1 illustrates the origins of the identification problem discussed in this paper. $^{5}$ Measurements of thoughts, feelings, and behaviors that arise from responses to incentives and social interactions are used to infer personality traits and abilities.

\footnotetext{
${ }^{3}$ See the models presented in John, Robins and Pervin (2008) and the survey in Cervone and Pervin (2009).

${ }^{4}$ This system is formalized in Almlund, Duckworth, Heckman et al. (2011).

${ }^{5}$ Almlund, Duckworth, Heckman et al. (2011) present a formal characterization of the identification problem and solutions to it.
} 
Personality traits and cognitive abilities, along with the other "units of analysis" in Figure 1, produce the measures that are used to infer the generating traits.

Behaviors include actions taken by agents whether in a task in the workplace, in interactions with others observed by third parties, or as measured by scores on tests of cognition or personality. To infer traits and abilities from measures requires "parsing out” or standardizing for all of the other factors that also produce the observed behavior, including incentives created by the situations in which people are placed. This is a challenging task. The difficulty in isolating traits from behaviors, thoughts or feelings gives rise to a fundamental identification problem. We illustrate this problem with two examples: (a) interpreting what IQ tests measure and (b) interpreting what achievement tests measure.

In Section 2, we report evidence that scores on IQ tests are determined by incentives and personality. Section 3 shows that scores on achievement tests and grades—often used as measures of cognition—are determined in substantial part by personality. Section 4 concludes.

\section{IQ Test Scores Reflect Incentives and Capture Both Cognitive and Personality Traits}

Isolating a pure measure of intelligence is difficult. It is commonly regarded as distinct from "noncognitive” or personality traits. By the definition of personality given in Section 1, intelligence is one aspect of personality. It is a measure of how well a person responds to (performs on) intelligence tests. (See Almlund et al., 2011.) 
Performance on intelligence (and achievement) tests depends in part on the personality traits of the test taker, apart from cognitive ability, as well as their motivation to perform. ${ }^{6}$ A smart child unable to sit still during an exam or uninterested in exerting much effort can produce low scores on an IQ test.

It is sometimes claimed that IQ tests measure maximal performance, i.e. that IQ scores reflect the application of the maximal capacity of the person to the tests. ${ }^{7}$ Inspection of Figure 1 suggests that IQ scores should be standardized for effort. A series of studies conducted over the past 40 years support this concern.

These studies show that among individuals with low baseline IQ scores, performance on subsequent IQ tests can be increased up to a full standard deviation by offering incentives such as money or candy for correct answers, particularly on groupadministered tests and particularly for individuals at the low-end of the IQ spectrum. ${ }^{8}$ Engaging in complex thinking is effortful, not automatic (Schmeichel, Vohs and Baumeister, 2003), and therefore motivation to exert effort affects performance. Borghans, Meijers and ter Weel (2008) and Almlund, Duckworth, Heckman et al. (2011) summarize the literature on the effects of incentives on IQ tests. See Table 1 in the Web Appendix, taken from Almlund, Duckworth, Heckman et al. (2011). ${ }^{9}$

\footnotetext{
${ }^{6}$ It is likely that performance on personality tests can also depend on cognitive ability, but that is less well documented. For example, it is likely that more intelligent people can ascertain the rewards to performance on a personality inventory test. Motivation is sometimes, but not often, counted as a personality trait. (See Borghans, Meijers and ter Weel, 2008.)

${ }^{7}$ A leading psychometrician, Carroll (1993), discusses this claim but does not accept the notion that IQ captures maximal effort.

${ }^{8}$ The incentives for invoking effort vary across studies.

${ }^{9}$ Zigler and Butterfield (1968) found that early intervention (nursery school, for example) for low-SES children may have a beneficial effect on motivation, not on cognitive ability per se. In their study, the benefits of intervention (in comparison to a no-treatment control group) on IQ were not apparent under testing conditions where motivation to perform well was maximal. Raver and Zigler (1997) present further evidence on this point. Heckman, Malofeeva, Pinto et al. (2011) show that the Perry Preschool program improved productive personality traits but did not raise IQ. The intervention has a 7-10\% annual rate of return.
} 
The response to incentives depends on personality traits. It is not enough to standardize for incentives to measure intelligence with IQ tests. One should also standardize for the personality traits that govern the response to incentives. Segal (2008) shows that introducing performance-based cash incentives in a low-stakes administration of the coding speed test of the Armed Services Vocational Battery (ASVAB) increases performance substantially, but only for roughly one-third of participants. Men with lower levels of the Big Five trait Conscientiousness are particularly motivated by incentives.

Borghans, Meijers and ter Weel (2008) show that adults spend substantially more time answering IQ questions when rewards are higher, but subjects high in the Big Five traits Emotional Stability and Conscientiousness are less affected by such incentives. They already operate at a high level even without these incentives. Similarly, Pailing and Segalowitz (2004) find that an event-related potential (ERP) indexing the emotional response to making an error increases in amplitude when incentives are offered for superior test performance. ${ }^{10}$ Thus, IQ scores do not accurately reflect maximal intellectual performance for individuals who are low in Conscientiousness and Emotional Stability. Performance on IQ tests encodes, in part, how effective persons may be in the application of their intelligence, that is, how people are likely to perform in some realworld settings.

Like low motivation, test anxiety can significantly impair performance (Hembree, 1988). That is, subjects do worse when they worry excessively about their performance, which causes their autonomic nervous system to over-react by increasing perspiration, heart rate, and so on. Individuals who are higher in Big Five Neuroticism are more likely

\footnotetext{
${ }^{10}$ An ERP is an electrophysiological response of characteristic form and timing to a particular category of stimuli.
} 
to experience test anxiety. This is another mechanism, beyond incentives, through which Emotional Stability can impact IQ scores (Moutafi, Furnham and Tsaousis, 2006).

Thus, IQ test performance captures not only pure intelligence, but also personality traits (including anxiety), intrinsic motivation, and reactions to extrinsic incentives to perform well, as suggested by Figure 1. The relative impurity of IQ tests likely varies from test to test and individual to individual. Little effort to date has been made to standardize the context and incentives of tests. To capture pure intelligence, it is necessary to adjust for incentives, motivations, and context in which the measurements are taken.

\section{Interpreting What Grades and Achievement Tests Measure}

The same issues discussed in regard to IQ tests apply with even greater force to achievement tests and grades. Achievement tests require factual knowledge acquired through schooling and life experience, which are, in part, determined by the motivation, curiosity, and persistence of the test taker. Cunha and Heckman (2008) and Cunha, Heckman and Schennach (2010) show that personality traits facilitate the accumulation of cognitive skills as measured by achievement tests. Thus, personality traits affect achievement test scores indirectly through the greater knowledge acquired by individuals with high levels of specific personality traits. Hansen, Heckman and Mullen (2004) and Heckman, Stixrud and Urzua (2006) show that schooling and other acquired traits substantially causally affect measured cognitive and personality test scores.

Achievement tests are typically designed to capture “general knowledge,” i.e., not knowledge of specific facts or the contents of specific courses, but the knowledge 
required to function effectively in modern society. ${ }^{11}$ Achievement tests attempt to capture different aspects of cognition than are captured by IQ tests, but scores on the two types of tests are highly correlated. As a result, the two types of measures are sometimes used interchangeably in popular and academic discussions. For example, Herrnstein and Murray (1994) use an achievement test as a measure of IQ. In later work, Nisbett (2009) uses achievement test scores as a measure of intelligence. We show that this is a dangerous practice. Achievement test scores depend on both personality and IQ. Empirical demonstrations of the importance of intelligence, based on scores on achievement tests or grades, are also demonstrations of the power of personality.

Table 1 displays the correlations among three widely used measures of cognition recorded in the adolescent years-IQ, an achievement test (the Armed Forces Qualifying Test or AFQT), and report card grades (in ninth grade). ${ }^{12,13}$ The correlations are large but by no means do the measures perfectly correlate.

Table 1 about here

It is well established that measures of intelligence and academic achievement predict a variety of social and economic outcomes although the $R^{2}$ of such predictive relationships rarely exceeds 10-15\%. ${ }^{14}$ Borghans, Golsteyn, Heckman et al. (2011) examine the predictive power of grades, IQ and achievement tests measured in the

\footnotetext{
${ }^{11}$ See Lindquist, Van Dyke and Yale (1948). Lindquist, along with Ralph Tyler, pioneered the concept of "general knowledge," which motivated the achievement test movement.

${ }^{12}$ The AFQT consists of four subtests: word knowledge, paragraph comprehension, arithmetic reasoning, and mathematics knowledge (Roberts, Goff, Anjoul et al., 2000, p. 19).

${ }^{13}$ Many interpret the AFQT as an IQ test. For discussion of the contrast between achievement and IQ tests see the collection of papers in Green (1974). Many of the contributors to that book do not think any distinction is meaningful.

${ }^{14}$ For evidence on the predictive power of cognitive measures, see, for example, Herrnstein and Murray (1994), Gottfredson (2008), Cawley, Heckman and Vytlacil (1999), Heckman, Stixrud and Urzua (2006), Taubman and Wales (1973), Jencks, Smith, Acland et al. (1972), and Bowles, Gintis and Osborne (2001).
} 
adolescent years for a variety of life outcomes past age $30 .^{15}$ The $R^{2}$ of most relationships is below 0.10 .

A general pattern emerges from their work. Achievement test scores are more highly correlated with outcomes than are IQ tests. The correlation of grades with outcomes is intermediate between IQ and achievement tests. Achievement tests and grades capture traits valued in economic and social life other than measured intelligence.

Grades and achievement test scores predict adult outcomes better than IQ because they also capture personality traits. This explains why achievement tests and grades have more predictive power than IQ. ${ }^{16}$ Another interpretation of their evidence is that acquired knowledge as captured by achievement tests and grades is more predictive than fluid intelligence as measured by IQ. As previously noted, personality traits affect the accumulation of knowledge.

Figure 2 presents evidence from two samples on the joint and individual contributions of IQ and personality measures to explaining the variance in achievement test scores and grades as measured by $R^{2}$. The first sample (results displayed in Panel A), extracted from the National Longitudinal Survey of Youth (NLSY79), is used to produce the correlations reported in Table 1 . The NLSY is a nationally representative sample of American youth. Youth were 14-22 at the date of initial enrollment (1979) and have been followed ever since. The second sample (results displayed in Panel B) shows the predictive power of IQ and personality measures on achievement scores and grades

\footnotetext{
${ }^{15}$ The outcomes include wages, income, hours worked, depression, smoking, physical activity, health, voting, divorce and unemployment.

${ }^{16}$ Duckworth, Quinn and Tsukayama (2010) present related evidence. See also Bowen, Chingos and McPherson (2009), Willingham, Pollack and Lewis (2002), and Duckworth and Seligman (2005).
} 
for a single Dutch high school (Stella Maris) sample in 2008. There is no long-term follow-up of this sample. ${ }^{17}$

Figure 2 about here

The NLSY data have relatively weak measures of personality: the Rosenberg measure of self-esteem and the Rotter locus of control. They are related to some of the Big Five traits. (See the discussion in Almlund, Duckworth, Heckman et al., 2011.) The Dutch data, while less representative and subject to the problem of restriction on range (only the students from the upper and middle level tracks are sampled—students from the lower track are not) have measurements of all of the Big Five inventory plus the Grit measure of persistence developed by Duckworth, Peterson, Matthews et al. (2007). The Differential Aptitude Test (DAT) measurement of achievement is very similar in content to the AFQT achievement test in the NLSY79. The range of correlations between DAT scores and AFQT scores in the NLSY data is from 0.76 to 0.80 (Borghans, Golsteyn, Heckman et al., 2011). ${ }^{18}$

In the American data (Panel A), 48\% of the variance in achievement scores and $21 \%$ of the variance in grades is accounted for by the combined influence of IQ and personality tests. Personality alone explains $16 \%$ and $7 \%$ of achievement tests and grades, respectively. The incremental contribution of personality to achievement and grades above the influence of IQ is $5 \%$ and $3 \%$ respectively. Stated differently, personality variables explain roughly a third of explained variance in achievement tests.

\footnotetext{
${ }^{17}$ A more comprehensive description of the data is given in the Web Appendix.

${ }^{18}$ Streicher and Friedman (1983) report correlations from .65 to .82 for 1,300 high school sophomores and juniors. Kettner (1976) found that for a group of juniors and seniors, DAT scores had multiple correlation coefficients ranging from .76 to .89 with the subtests of the AFQT.
} 
These results are remarkable in light of the weak measures of personality in the NLSY data.

The Dutch data (Panel B) show a similar pattern. Due to restriction on range, the variance explained by IQ and personality measures is smaller. The relative contribution of personality to explained variance is proportionately greater than in the American data. The evidence on grades is especially striking. Personality traits explain virtually all of the variance in grades.

\section{Summary}

This paper discusses and illustrates a fundamental identification problem in personality psychology. Traits are typically measured by behaviors, broadly defined to include observer reports and performance on tests. Behaviors are influenced by incentives and by traits other than the traits that the various measures seek to capture. In order to isolate any individual trait, it is necessary to control for all other traits and incentives.

We offer direct evidence on the relevance of these concerns. Using two sources of data from the U.S. and the Netherlands, we establish that a substantial portion of the variance in grades and achievement tests is predicted from measures of personality. The incremental contribution of personality above and beyond IQ is substantial in both data sets. Personality is particularly powerful in explaining the variation in grades. ${ }^{19}$

\footnotetext{
${ }^{19}$ See the evidence in Duckworth and Seligman (2005) and Duckworth, Quinn and Tsukayama (2010).
} 
This explains the greater predictive power of achievement tests and grades than IQ for a variety of life outcomes. Personality plays a powerful role in predicting life outcomes (see Almlund, Duckworth, Heckman et al., 2011).

The common practice of equating measurements with traits is not justified. ${ }^{20}$ Thus, when Herrnstein and Murray (1994) show the power of AFQT in predicting life outcomes, they are not establishing the power of IQ or " $g$," as they claim to have done. Without standardizing for personality traits, their correlations show the combined effect of cognition and personality on life outcomes. ${ }^{21}$

\footnotetext{
${ }^{20}$ Almlund, Duckworth, Heckman et al. (2011) present a formal statement of this problem and some econometric solutions.

${ }^{21}$ Borghans, Golsteyn, Heckman et al. (2011) show that adjusting for personality reduces the predictive power of achievement tests for some later life outcomes.
} 


\section{References}

Almlund, M., Duckworth, A. L., Heckman, J. J., \& Kautz, T. (2011). Personality psychology and economics. In. E. A. Hanushek, S. Machin, \& L. Wößmann (Eds.), Handbook of the economics of education Amsterdam, Elsevier.

Borghans, L., Golsteyn, B. H. H., Heckman, J. J., \& Humphries, J. E. (2011). Reinterpreting estimated effects of cognition on social outcomes. Unpublished manuscript. Department of Economics, University of Chicago.

Borghans, L., Meijers, H., \& ter Weel, B. (2008). The role of noncognitive skills in explaining cognitive test scores. Economic Inquiry, 46, 2-12.

Bowen, W. G., Chingos, M. M., \& McPherson, M. S. (2009). Test scores and high school grades as predictors. Crossing the finish line: Completing college at America's public universities. Princeton, NJ: Princeton University Press.

Bowles, S., Gintis, H., \& Osborne, M. (2001). The determinants of earnings: A behavioral approach. Journal of Economic Literature, 39, 1137-1176.

Carroll, J. B. (1993). Human cognitive abilities: A survey of factor-analytic studies. New York: Cambridge University Press.

Cawley, J., Heckman, J. J., \& Vytlacil, E. J. (1999). On policies to reward the value added by educators. Review of Economics and Statistics, 81, 720-727.

Cervone, D., \& Pervin, L. A. (2009). Personality: Theory and research. Hoboken, NJ: John Wiley and Sons. 
Cunha, F., \& Heckman, J. J. (2008). Formulating, identifying and estimating the technology of cognitive and noncognitive skill formation. Journal of Human Resources, 43, 738-782.

Cunha, F., Heckman, J. J., \& Schennach, S. M. (2010). Estimating the technology of cognitive and noncognitive skill formation. Econometrica, 78, 883-931.

Duckworth, A. L., Peterson, C., Matthews, M. D., \& Kelly, D. R. (2007). Grit: Perseverance and passion for long-term goals. Journal of Personality and Social Psychology, 92, 10871101.

Duckworth, A. L., Quinn, P. D., \& Tsukayama, E. (2010). What No Child Left Behind leaves behind: The roles of IQ and self-control in predicting standardized achievement test scores and report card grades. Unpublished manuscript. University of Pennsylvania, Department of Psychology.

Duckworth, A. L., \& Seligman, M. E. P. (2005). Self-discipline outdoes IQ in predicting academic performance of adolescents. Psychological Science, 16, 939-944.

Gottfredson, L. S. (2008). Of what value is intelligence? In A. Prifitera, D. Saklofske, \& L. G. Weiss (Eds.), WISC-IV applications for clinical assessment and intervention. Amsterdam, Elsevier.

Green, D. R. (1974). The aptitude-achievement distinction. Monterey: McGraw-Hill.

Hansen, K. T., Heckman, J. J., \& Mullen, K. J. (2004). The effect of schooling and ability on achievement test scores. Journal of Econometrics, 121, 39-98.

Heckman, J. J., Malofeeva, L., Pinto, R., \& Savelyev, P. A. (2011). Understanding the mechanisms through which an influential early childhood program boosted adult outcomes. Unpublished manuscript. Department of Economics, University of Chicago. 
Heckman, J. J., Stixrud, J., \& Urzua, S. (2006). The effects of cognitive and noncognitive abilities on labor market outcomes and social behavior. Journal of Labor Economics, 24, 411-482.

Hembree, R. (1988). Correlates, causes, effects, and treatment of test anxiety. Review of Educational Research, 58, 47-77.

Herrnstein, R. J., \& Murray, C. A. (1994). The bell curve: Intelligence and class structure in American life. New York: Free Press.

Jencks, C., Smith, M., Acland, H., Bane, M. J., Cohen, D. K., Gintis, H., Heyns, B., \& Michelson, S. (1972). Inequality: A reassessment of the effect of family and schooling in America. New York: Basic Books.

John, O. P., Robins, R. W., \& Pervin, L. A. (2008). Handbook of personality: Theory and research. New York, NY: The Guilford Press.

Kettner, N. (1976). Armed Services Vocational Aptitude Battery (ASVAB Form 5): Comparison with GATB and DAT tests. Los Angeles: Contemporary Research, Incorporated.

Lindquist, E. F., Van Dyke, L. A., \& Yale, J. R. (1948). What good is high school? Chicago, Science Research Associates.

Moutafi, J., Furnham, A., \& Tsaousis, I. (2006). Is the relationship between intelligence and trait neuroticism mediated by test anxiety? Personality and Individual Differences, 40, 587597.

Nisbett, R. E. (2009). Intelligence and how to get it: Why schools and cultures count. New York, NY: WW Norton \& Company. 
Pailing, P. E., \& Segalowitz, S. J. (2004). The error-related negativity as a state and trait measure: Motivation, personality, and ERPs in response to errors. Psychophysiology, 41, 84-95.

Raver, C. C., \& Zigler, E. F. (1997). Social competence: An untapped dimension in evaluating Head Start's success. Early Childhood Research Quarterly, 12, 363-385.

Roberts, B. W. (2006). Personality development and organizational behavior. In B. Staw (Ed.), Research on Organizational Behavior (pp. 1-41). Oxford, UK, Elsevier Science/JAI Press.

Roberts, B. W. (2009). Back to the future: Personality and assessment and personality development. Journal of Research in Personality, 43, 137-145.

Roberts, R. D., Goff, G. N., Anjoul, F., Kyllonen, P. C., Pallier, G., \& Stankov, L. (2000). The Armed Services Vocational Aptitude Battery (ASVAB): Little more than acculturated learning (Gc)!? Learning and Individual Differences, 12, 81-103.

Schmeichel, B. J., Vohs, K. D., \& Baumeister, R. F. (2003). Intellectual performance and ego depletion: Role of the self in logical reasoning and other information processing. Journal of Personality and Social Psychology, 85, 33-46.

Segal, C. (2008). Motivation, test scores, and economic success. Department of Economics and Business, Universitat Pompeu Fabra, Working Paper No. 1124.

Streicher, A. H., \& Friedman, D. (1983). Armed Services Vocational Aptitude Battery (ASVAB Form 14): Comparison with CAT, DAT, and Fit/Fact Tests. Unpublished report. Rockville, MD: Research Applications, Inc.

Taubman, P. J., \& Wales, T. J. (1973). Higher education, mental ability and screening. Journal of Political Economy, 81, 28-55. 
Willingham, W. W., Pollack, J. M., \& Lewis, C. (2002). Grades and test scores: Accounting for observed differences. Journal of Educational Measurement, 39, 1-37.

Zigler, E. F., \& Butterfield, E. C. (1968). Motivational aspects of changes in IQ test performance of culturally deprived nursery school children. Child Development, 39, 1-14. 


\section{Table 1. Correlations Among NLSY79 Measures of Cognition}

\begin{tabular}{llll}
\hline \hline & \multicolumn{3}{l}{ Correlation between IQ, AFQT, and GPA } \\
\hline & $\underline{\text { IQ }}$ & $\underline{\underline{\text { Achievement }}}$ & $\underline{\underline{\text { Grade Point Average }}}$ \\
IQ & 1 & $\underline{\text { (GPA) }}$ & \\
AFQT & 0.65 & 1 & \\
GPA(9th) & 0.42 & 0.54 & 1 \\
\hline \hline
\end{tabular}

Source: National Longitudinal Survey of Youth (NLSY79). Pooled male and female random sample.

Notes: The Armed Forces Qualifying Test (AFQT) was administered in 1980 when subjects were 15-22. AFQT is adjusted for schooling at the time of the test conditional on final schooling, following the procedure in Hansen, Heckman and Mullen (2004). AFQT is constructed from Arithmetic Reasoning, Word Knowledge, Math Knowledge, and Paragraph Comprehension tests. IQ and GPA are from high school transcripts. IQ is pooled across several IQ tests using IQ percentiles. GPA is the individual's coresubject GPA measured in $9^{\text {th }}$ grade when virtually all sample participants are enrolled. Differences between males and females are slight. For the sake of brevity we report pooled results. 


\section{Figures}

Figure 1. Roberts's model of personality as the output of a system

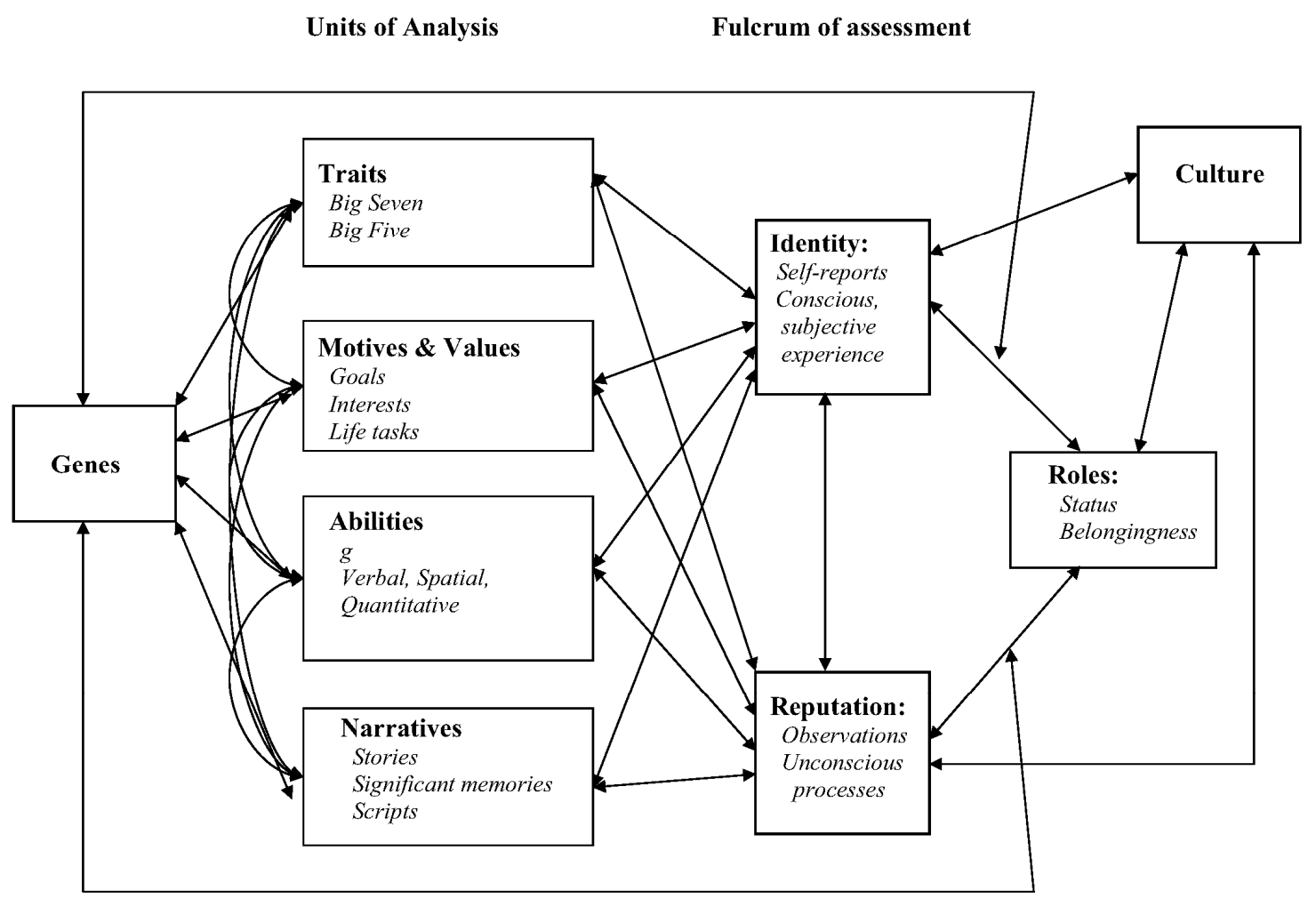

Source: Roberts [2006]. 
Figure 2: Decomposing achievement tests and grades into IQ and personality

(A) NLSY79

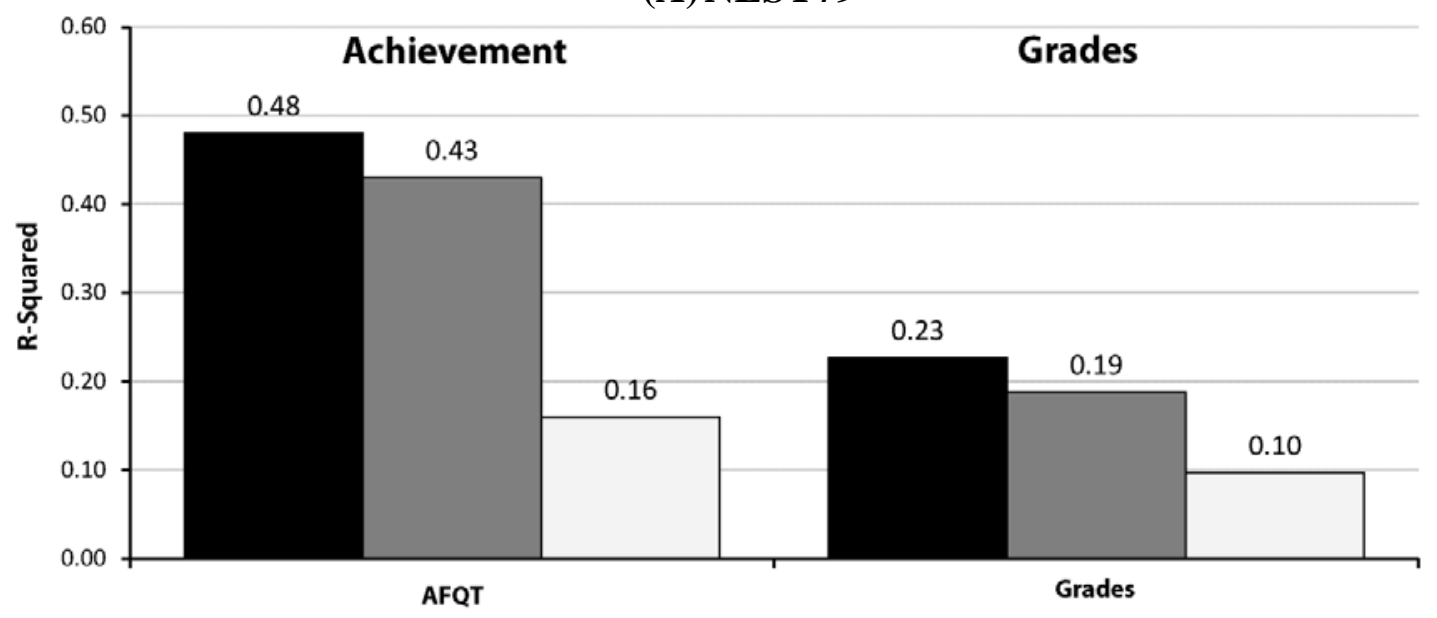

$\square$ IQ, Rosenberg, and Rotter $\square$ IQ $\square$ Rosenberg and Rotter

(B) Stella Maris

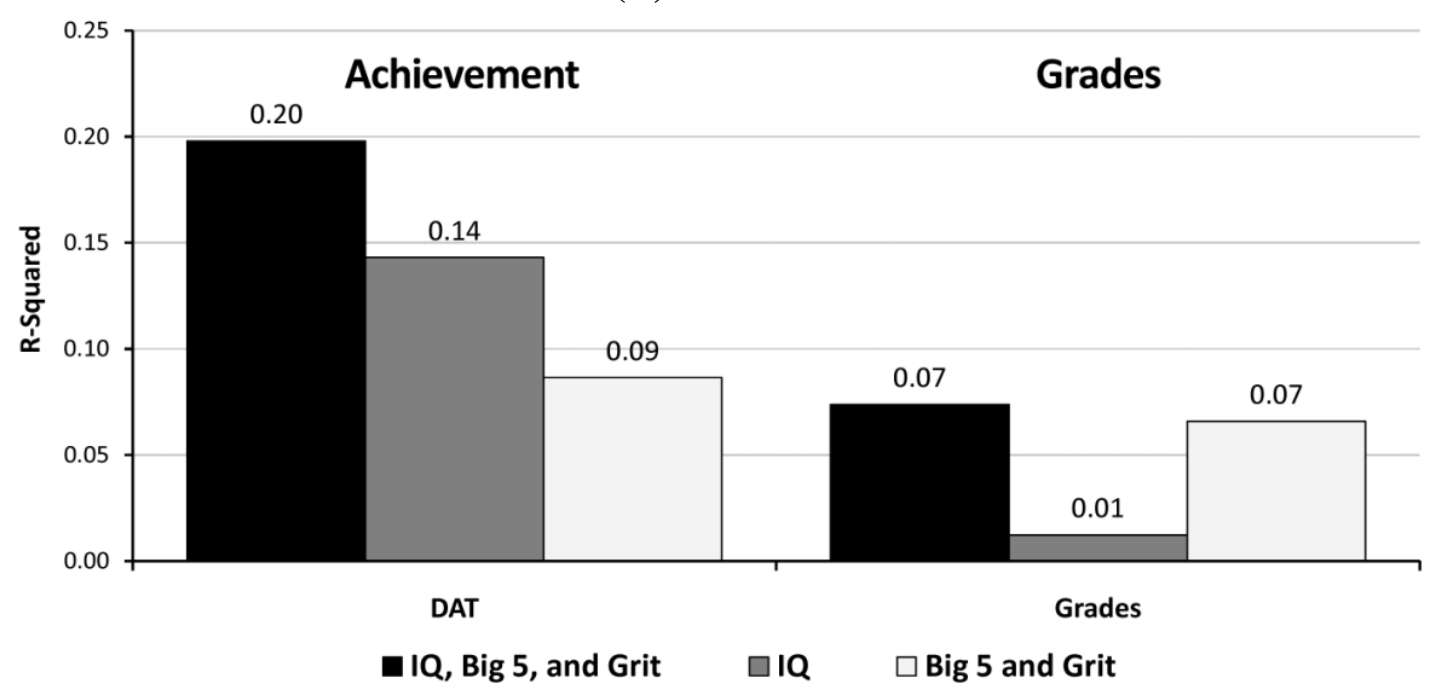

Source: Borghans, Golsteyn, Heckman et al. [2011].

Notes: Rotter was administered 1979. The ASVAB and Rosenberg were administered in 1980. AFQT is constructed from the Arithmetic Reasoning, Word Knowledge, Mathematical Knowledge, and Paragraph Comprehension ASVAB subtests. IQ and GPA are from high school transcript data. AFQT, Rosenberg, and Rotter have been adjusted for schooling at the time of the test conditional on final schooling, as laid out in Hansen, Heckman and Mullen [2004]. IQ is pooled across several IQ tests using IQ percentiles. GPA is the individual's core subject GPA from 9th grade. Sample excludes the military over-sample. 